\title{
Editorial
}

\section{Changes in brand management}

I first moved into brand management over 25 years ago. Since then I have worked for several companies in various positions ranging from product manager through to product group manager, international marketing manager, general manager, sales and marketing director, divisional manager, managing director and chief executive. But I have always had an element of responsibility for brand management. I have seen and experienced many changes in the way that brand management is perceived.

\section{MARS}

I moved from sales management into brand management while working for the Mars Corporation. I was employed by Pedigree Petfoods, a very profitable division of Mars. The brand manager was responsible for all elements of the brand. He or she ran it like a mini company, as a mini managing director, and acted as the hub of the wheel, with relationships with all the spokes of the wheel of the company. The brand manager was based in the factory where the product was produced and wore a coat, blue in my case, to identify him or her with other managerial staff based in the factory. The brand manager was responsible for the product formulation, which was agreed with R\&D after appropriate animal testing. Every morning there was a meeting with representatives of production, $\mathrm{R} \& \mathrm{D}$ and quality assurance to review the previous day's output. The quality was reviewed against agreed standards and often there would be debate over whether it was acceptable or should be rejected. And, yes, it is true, in the desire to check this quality thoroughly, it was not unknown for managers to actually taste the product themselves.

Any proposal to fundamentally change the product, its packaging or advertising, or to add a new variety, was the subject of a recommendation to the board of directors. The brand manager produced these recommendations and was responsible for arguing the case and getting signed agreement from all interested parties. Even then there might be further scrutiny of the evidence. I well remember a formidable finance director asking to review the market research that underpinned a major change in formulation of a product in my care.

Production plans and sales forecasts were reviewed monthly with the planning managers and sales managers. Again it was the brand manager's responsibility to get agreement to his or her plans. The delivery of a profit target was the ultimate responsibility of the brand manager. This was set as a 'marginal balance' on the profit and loss of the brand. It had to contribute to the achievement of a return on total assets, which was the overall measurement of the company's profitability.

In my case the factory to which I was attached could not achieve its profit targets purely from sales in the domestic market, and needed to achieve sales in export markets. In the more developed of these there were Mars marketing companies set up to exploit the brand properties of the 
various Mars divisions in those domestic markets. Of course, there were local brand managers in each of these markets who were responsible for positioning the brand in these countries. They liaised with the exporting factory over forecasts, labelling and packaging, and they worked with their sales force to achieve distribution through the relevant channels. The product manager in the factory therefore acted as a proxy for the overseas brand manager in his relationships with the other functions, particularly production and $\mathrm{R} \& \mathrm{D}$. One of the brands for which I was responsible was positioned better in Germany than in the UK, and I spent much of my time liaising with my opposite number in Germany over his brand. He happened to be British, but, to add to the dynamics of the situation, if the volume reached a certain point his management might be tempted to build a production line in their own factory and take the volume away from ours.

Such negotiations prepared me for a wider international role, this time based in a Los Angeles factory. The US dollar was going through one of its weaker periods and the US company saw the opportunity to expand its sales overseas to other markets. I helped secure business in Japan, competing with a sister factory in Australia, and in Puerto Rico through a sister marketing company. I tried to get round the tariff barriers of Canada, also working with a sister marketing company. Finally I opened up the market in Chile for prepared petfoods. In so doing I recommended that a proper marketing unit should manage the market, which was opening up in the early 1980s in an exciting way. When you make such a recom- mendation, you should know what to expect. Sure enough, I was asked to found such a company. I did so and we worked with all the Mars factories in North America to exploit the opportunities in Chile. This was the first marketing company established by Mars in the whole of Latin America, and it was seen as a prototype for the future as other larger markets freed up.

So I was now at the other end, close to the market and relying on the export staff and the marketing managers in the home factories to look after the product quality. The attention to detail in product quality was remarkable. The whole ethos of the company was rooted in finding a unique selling proposition for each brand and then ensuring that all elements of the marketing mix were well managed to execute well and deliver a satisfactory product. When it was well executed, there were significant brands built.

\section{PILLSBURY}

I then moved to Pillsbury, another US-based food corporation with a history of great brand development. The Pillsbury Dough Boy and the Jolly Green Giant were among the most recognisable properties in brand management, and these characters were mnemonics for excellent brand values. I was responsible for Green's of Brighton, a profitable cash cow with its own factory producing a rather outdated portfolio of products, all sold under the Green's brand. It is still with us today, although it has since gone through a series of owners. Pillsbury had been built on brand values, but was coming under the thumb of Wall 
Street, and some of its brand values were starting to erode. I was asked to deliver a bottom-line contribution, even if that was at the expense of brand value. You can do that for so long but not indefinitely. I moved on before the trouble came, but I knew it would. Actually it came in the guise of an acquisitor, Grand Metropolitan, now Diageo. Over time the food business of Pillsbury that also included Burger King restaurants and Häagen-Dazs ice cream has been broken up. I believe that the private ownership of Mars was a better haven for brands than the public ownership of Pillsbury.

\section{SONY}

I then became Managing Director of Sony UK Consumer Products Division. While obviously different from foods, the brand values of consumer electronics in those days primarily rested on product quality, as well as good design and clear positioning. Much of what we sold in the UK was still imported from Japanese factories, although we had an excellent factory in the UK producing most of our television products. The 'Made in Japan' label on the product was seen as an important endorsement of product quality, an irony in the history of Japanese manufacturing not lost on the co-founder of Sony, Akio Morita, who titled his autobiography 'Made In Japan'.

The Japanese yen was rising and the problem of how to remain competitive with cheaper products from lowercost sources began to affect all the famous Japanese companies. Sony had first built a factory in Wales for strategic reasons. As a global company it knew it would not be acceptable long term for all the products to be imported from Japan. Televisions are a product that is particularly subject to political influence. Television standards vary by region: there are eight variations in Europe even today. Broadcasting is usually controlled, and technical innovations like NICAM stereo - a BBC invention - are often developed locally. The products are bulky and expensive to ship worldwide. So for all these reasons, rather than purely cost, it made sense to produce televisions close to the market. We at Sony would take our dealers to the factory to convince them that the quality was as good as if it had been made in Japan. The workforce was all recruited locally, but most of the senior management came from Japan to ensure standards were maintained. And they were. At its best, the Sony factory in Wales was rated in the top ten of Sony factories worldwide.

Nevertheless the cost pressures of a strong yen increased, and Sony began to export production. In the UK we started to import audio products from Malaysia and Thailand. Over time we took our dealers to these factories too, so that they could see that the same philosophy was maintained in all these places to ensure an excellent final product. More and more of Sony's production was exported overseas. There were advantages that came from this: it was more politically acceptable to produce closer to the markets. But there can be no doubt that companies like Sony have been strongly tested to maintain their product quality as they have widened their sources of production. The requirements on the brand manager are tough. To centralise all the decisions about product design and target quality becomes harder. Com- 
panies like Sony that use one allpowerful corporate brand as the single umbrella endorsement must maintain a very strong sense of pride in the standards that the brand represents. The more diverse the sources of production, the more diverse the products that carry the brand, and the harder that becomes.

Sony, of course, had already started to license the brand. In Japan, where the strength of the brand is even greater than in overseas markets, the brand is often used in the most unlikely ways. I used to collect the more outlandish uses on my frequent trips to Japan, and in my braver moments would raise these with top management as potential threats to the integrity of the brand. Nevertheless, in my ten years with Sony I have to say that for most of that time I was in awe of the power of the brand and what had been achieved by single-minded commitment to quality design and innovation over many years.

\section{PENTLAND GROUP}

I then joined a British brand owner, Pentland Group plc. I took board responsibility for the group's various international brands. Pentland had made a huge return on its investment in Reebok. Its particular skills were more in sourcing than in brand management. It was one of the first shoe companies to source from the Far East, and over the years had developed significant expertise in this area. As a result it won the footwear licences from both Kickers and Lacoste, two very different French brands. Lacoste was one of the first to build its brand, initially on the sporting exploits of its eponymous founder, Rene Lacoste, star of French tennis in the 1930s, and then on the licensing model, where it franchised its brand to companies such as Pentland for exploitation in various markets. There were, I believe, just six such licensees, but Lacoste managed them very tightly. Lacoste in Paris nominated no less than six staff to manage the relationship with Pentland to ensure that our efforts were up to their mark. But of course, neither company was actually manufacturing the shoes. Lacoste was licensing its brand to Pentland, who in turn designed and then sourced products from low-cost Asian factories. We retained key staff, known colloquially as 'shoe-dogs', who understood the mechanics of shoe production. Typically these were mature individuals who had started their career with great shoe producers like Clarks. It is difficult to know where such skills will be found in the future.

Pentland had also used some of the Reebok proceeds to buy other great brands like Speedo in Australia, Ellesse in Italy, Reusch in Germany and Berghaus and Mitre in the UK. All of these had great traditions built on original strong product values, but over the years they had become fragmented in ownership and positioning. The manufacturing base of these companies was still there, but the majority of production was outsourced. The product quality that the home factories could achieve could not be matched in the cheaper offshore factories, but the market would not pay the premium necessary to justify maintaining these factories, and over time most of them were downsized or closed. Pentland is not alone in this, of course. It is the route followed by most of the great brand owners in sports and 
leisure wear. Pentland brand management skills therefore have to be in managing the outsource, in managing licence agreements both as licensor and licensee, and in managing the communication of the brand values to the target audience.

\section{NXT}

In my current position I have got even further away from manufacturing, but am still trying to build a brand. NXT is a technology licensing company. We have made inventions that enable the creation of flat-panel loudspeakers. We have protected these inventions in a comprehensive portfolio of patents that have been granted or are going to be granted worldwide, and we have chosen the business model of licensing the use of the patents. At the same time we have registered the brand name NXT, which stands for 'New Transducers Technology'. ' $\mathrm{X}$ ' is a symbol for a transducer (there already is an NTT!). Following the excellent example of Dolby, we are seeking to establish a brand that will have perpetual life beyond the expiry of the patents. Mr Dolby's useful patents in noise reduction expired years ago, but he is still able to collect a royalty on the use of his brand name. I hope to write about the challenges in building a worldwide technology brand in a future issue.

\section{GLOBAL TRENDS}

Looking back over my 25 years in brand management I seem to see, written small, the trends that have happened worldwide. The developed economies are producing less and less, but have perfected ways of sourcing their products, perhaps with some compromise in quality, while retaining ownership and management of the brand that unifies the whole proposition. But there must be risks in this. Many of the companies that have been happy to be production sources are starting to become brand owners too. TCL, for example, a major Chinese producer of televisions, has 'merged' with Thomson Consumer Electronics, the owners of the powerful Thomson brand in Europe and RCA brand in the USA. It can only be a matter of time before TCL is managing the brands Thomson and RCA from its own production base in China.

\section{IN THIS ISSUE}

In this issue, the Journal of Brand Management covers: a conceptual model for strategically leveraging partner brand equity; making the case for a new brand name; applying causal modelling to measuring and building brand equity in the energy market; and a cross-cultural study addressing likeability and brand recall in Asia. When reading these papers, I suggest that you also consider the extent to which the skills of the brand manager have been stretched by the challenges of globalisation. 